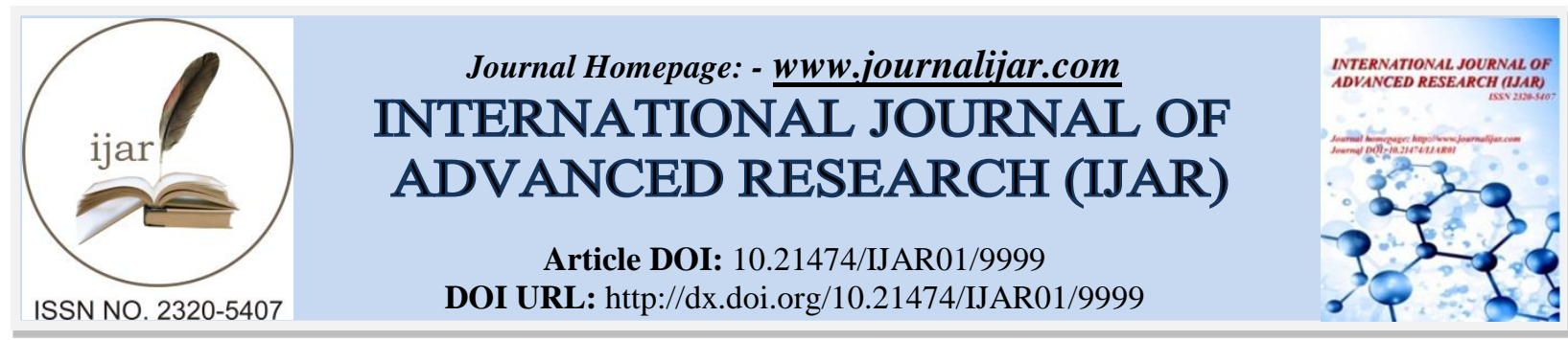

RESEARCH ARTICLE

\title{
CHARACTERIZATION OF MORPHOLOGY, ANATOMY AND CHLOROPHYLL CONTENT OF POTATO IN VITRO AND IN VIVO.
}

Warnita Warnita, Reni Mayerni, Nilla Kristina and Rohmi Suwinda.

Department of Agronomy, Faculty of Agriculture, Andalas University, Padang, Indonesia.

\section{Manuscript Info}

Manuscript History

Received: 05 September 2019

Final Accepted: 07 October 2019

Published: November 2019

Key words:-

characterization, morphology, anatomy, chlorophyll, potatoes.

\begin{abstract}
Potato plants are horticultural crops of vegetables are widely used community for the nutrient content is high enough. Characterizaion of morphology and anatomy and chlorophyll content of plants grown in vitro is different from in vivo. The purpose of this study is to see characterization of morphology, anatomy and chlorophyll content of potato plants in vitro and in vivo. This research has been done on plants tissue culture laboratory of the Faculty of Agriculture and the Basic Laboratory Andalas University, Padang from July to October 2019. Research of the experiment by observing the morphology, anatomy and chlorophyll content of the potato plant. Observations were made of the morphology of the potato plant in vitro and in vivo. For anatomical observations carried out with a microscope and chlorophyll test with a spectrophotometer. The results showed that there were differences in morphology, anatomy and chlorophyll content of the potato plant in vitro to in vivo. Stomata on the upper surface of the leaf are fewer than the bottom of the leaf. Chlorophyll content of the potato plant in vitro less than in vivo.
\end{abstract}

Copy Right, IJAR, 2019,. All rights reserved.

\section{Introduction:-}

Potato plants originate from South America (Peru, Chile, Bolivia, and Argentina) as well as some areas of Central America. In mainland Europe it is estimated plant was first introduced from Peru and Colombia through Spain in 1570 and in England in 1590. The spread of potatoes to Asia (India, China, and Japan), Africa, and the islands of the West Indies undertaken by people the British in the late $17^{\text {th }}$ century and in these areas the potatoes planted widely in the mid $18^{\text {th }}$ century [1].

In tropical Indonesia, potatoes are generally planted in an area with a height of more than 1,000 $\mathrm{m}$ above sea level. Short-lived potato plants or bushes shaped high plants can reach $100 \mathrm{~cm}$ above the ground (in vivo), including crops that produce only one time after the death. Potato plants consisting of stolon, tubers, stems, leaves, flowers, fruits, seeds, and roots and have the time of harvest between 90-120 days. Forms of potato tubers include round, oval and elongated oval. Bulbs eyes are shallow and deep. Potato plant stems are round or triangular wings, nodes and hollow. Leaves elliptical or oval with a sharp tip. Potato plants have primary and secondary leaflets arranged in petiole face to face. Potato flower shaped like a trumpet and appear at the ends of branches. Flower petals are green and there are five sheets [2]

Corresponding Author:- Warnita Warnita.

Address:- Department of Agronomy, Faculty of Agriculture, Andalas University, Padang, Indonesia. 
Several varieties of potatoes were cultivated to own character, form, requirements grow, altitude, time of harvest which is not the same. The average height of potato plants of Granola variety aged 11 weeks after planting ranges from $80-95 \mathrm{~cm}$ with a stem thickness of $20 \mathrm{~cm}$ with spreading habit, a type of leaf arrangement that is slightly open with a flower size of $3.3 \mathrm{~cm}$ and a violet blue color [3]. Sari [4] add the potato tuber Granola varieties have yellow flesh tubers, bulbs eyes shallow and rounded tuber shape and high reducing sugar content and low dry weight percentage $(16-17 \%)$.

Propagation of Granola potato varieties in vivo planted on medium plains (300-700 m asl) and in vitro potatoes (tissue culture) under conditions and treatment under two different conditions allows changes in morphological, anatomical and chlorophyll content. The process of photosynthesis associated with leaf anatomy. Leaves covered the surface of each layer of the epidermis.

Stomata are on both sides. Mesophyll tissue did not differentiate into palisade tissue and spongy tissue, but consists of parenchyma cells with chloroplasts and the space between cells in between. Stomata are pores between the epidermis flanked by 2 special epidermal cells called guard cells. Near guard cells are cells that surround called subsidiary cells. Guard cell can be opened and closed in accordance with the needs of the plant need transpiration, while subsidiary cells participate in osmotic changes related to the movement of the guard cell. Stomata present in all parts of the plant were exposed to the air, but more abundant in leaves [5].

Dicotyledonous guard cells are generally kidney-shaped, whereas monocots have a specific uniform shape and structure which when viewed from the cell surface looks narrow in the middle and enlarges at the ends. Viewed with an electron microscope, the protoplast of the two guard cells is interconnected through the enlarged wall pore. Because of this continuity, the guard cells are considered a physiological unit in which there is a balance of turgor changes. Radial orientation of cellulose microfibrils in guard cell walls can also be seen with a polarizing microscope [6].

According to Retno [7] stomata is a modification of specialized epidermal tissue into an organ that acts as the entry and exit of air and water in the leaves. Rompas [8] states that stomata are commonly found on the underside of leaves, but there are several plant species with stomata on the upper and lower surfaces of leaves.

In this study also calculated the density and stomata index and chlorophyll content in addition to morphology and anatomy in potato plants in vivo and in vitro. This study aims to look at differences in morphology, anatomy and chlorophyll content of potato plants in vivo and in vitro.

\section{Materials and Methods:-}

Location and time-

This research was conducted in the Laboratory of Plant Tissue Culture of the Faculty Agriculture and the Basic Laboratory of Andalas University, Padang. The research was conducted from July to October 2019.

\section{Materials and tools-}

The material used was a variety of Granola potato plants taken from Sukarami, Solok Regency and Laboratory of Plant Tissue Culture, Faculty of Agriculture, Andalas University, Padang. The chemicals used are MS medium, 70\% alcohol, chlorox, and $80 \%$ acetone. Tools used are knives, scissors, microscopes, spectrophotometers, cameras and stationery.

\section{Research methods-}

The method was carried out by descriptive method. With this method researchers can see, explain or explain the morphological character of potato plants. Sampling was done intentionally (purpusive sampling). For each character 3 samples were determined. Data collection and observation samples were carried out directly.

\section{Implementation-}

Morphological characters observed included roots, stems, leaves and tubers which refer to the International Union for the Protection of New Varieties of Plants (UPOV) descriptor [9] and Tjitrosoepomo's plant morphology book [10]. Data collection and observation samples were carried out directly. 
Anatomical characters observed were stomata shape, stomata index and stomata density and starch content. Observation of stomata on leaves was observed on the lower surface of the leaf and the upper surface of the leaf under a microscope, counting the number of stomata, the data were processed using the Image $\mathrm{J}$ application, where the stomata index was calculated by the formula: (Willmer, 1983).

$$
\text { Stomatal index }=\frac{\Sigma \text { stomata }}{\Sigma \text { stomata }+\Sigma \text { epidermal cells }} \times 100
$$

Data on stomatal density is calculated using the formula:

$$
\text { The density of stomata }=\frac{\text { number of stomata }}{\text { area of view }(\text { um })}
$$

Presentation of data in this study is in the form of tables and figures resulting from observations of the morphological and anatomical characters of potato varietis of Granola. Then analyzed with analysis techniques descriptive.

\section{Results and Discussion:- \\ Morphological characterization}

The morphological characters observed in this study are some morphological characters that refer to Tjitrosoepomo's morphological characters and some additional characters from the International Union for the Protection of New Varieties of Plants (UPOV) descriptors. Plants that were studied were varpetas Granola potato plants with the Latin name Solanum tuberosum L. plant Morphology is the study of the physical form and structure of the body of the plant, derived from the Latin morphology Morphus which means form or shape. To make it easier for researchers to classify plant species, morphological form is an indicator of a very large role to identify plants visually, so that the diversity of plants that are very diverse can be identified and classified to facilitate the naming of species, families and kingdoms. [10]

Morphological characteristics of plants observed include root (radix), stem (caulis), leaf parts (folium) along with their shape, leaf type, leaf layout, and potato tuber origin in vivo and in vitro. There are differences in morphological characteristics of potatoes in vivo and in vitro quantitatively and qualitatively (Table 1).

\begin{tabular}{|c|c|c|}
\hline Character & In vivo & In vitro \\
\hline - Harvesting & $110-114$ hst & $112 \mathrm{hst}$ \\
\hline - $\quad$ Originally propagation & Tuber & Micro cuttings \\
\hline - $\quad$ Plant height & $60-70 \mathrm{~cm}$ & $5-10 \mathrm{~cm}$ \\
\hline - The shape of the roots & Stables (primaria) & Fibers (adventicia) \\
\hline - $\quad$ The stem shape & Cornered (angular) & Round (teres) \\
\hline - Leaf shape & $\begin{array}{c}\text { Compound leaves (Folium } \\
\text { Compositum) }\end{array}$ & Single leaf (folium simplex) \\
\hline - $\quad$ The tip of the leaf & Tapered (acuminatus) & Rounded (rotundus) \\
\hline - $\quad$ Leaf base & Blunt (obtusus) & Blunt (obtusus) \\
\hline - $\quad$ Leaf edge & Bertoreh choppy (repandus) & Average (integer) \\
\hline - $\quad$ Leaf surface & Hairy (pilosus) & Hairy (pilosus) \\
\hline - $\quad$ Tuber shape & Oval & Oval \\
\hline
\end{tabular}

Table 1:-Morphological characters potatoes in vivo and in vitro

The results showed that there were similarities and differences in morphological forms between potato plants in vitro and in vivo. The morphology of potato plants is influenced by the location and the environment. Potato root in vitro is a fibrous root because it comes from micro cuttings. According to Salisbury and Ross [11] leaves that are exposed to high light intensity during their development can affect the leaf area, ie small, thick leaves.

The stem (caulis) -

The shape of the stem based on their cross section can be divided into round (teres), angular (angularis), and flat which are usually then broadened to resemble leaves and take over the task of leaves as well. Stems can also be characterized by their surface characteristics, whether slippery (laevis), ribbed (costatus), grooved (sulcatus), winged (tool), haired (pilosus), prickly (spinous), and so on. 
Potato stems of Granola varieties in vivo in this observation are in the form of pentagons, beams, round hairy stems (pilosus), hollow and not woody with bright green stems, while the stems of Granola varieties in vitro based on their cross sections are round (teres), and the nature of the hairy face (pilosus) with the upright stem (erectus) (Figure 1).

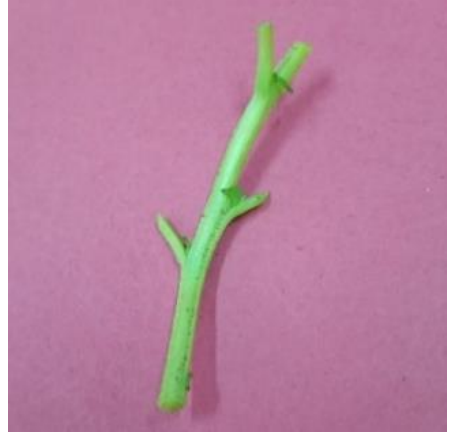

A

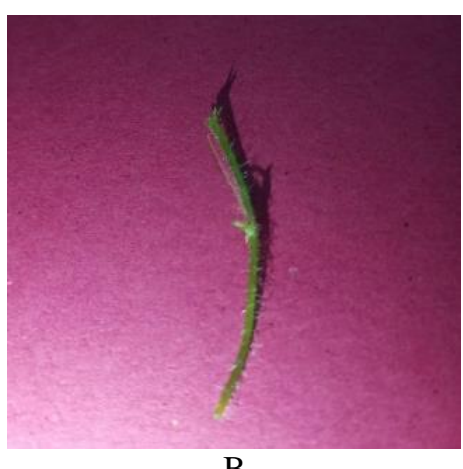

B

Figure 1:-Stem potato (A) in vivo and (B) in vitro

A high temperatures allows elongation of the stem so that new stems from stolons are formed that appear on the surface of the growing media. Stems below the surface of the soil called stolons hoard and store photosynthetic products in bulbs that swell at the end. Carbohydrates are transplanted as sucrose into stolons where cell division and enlargement causes tuber growth [12].

The direction of stem growth also varies, such as perpendicular (erectus), hanging (dependent, pendulus), lying (humiphus), spreading or crawling (repensing), upward inclining or inclining (ascending), nodding (nutans), climbing (climbing) scandens), and convolution (volubilis) [10]. However, potato plants generally have three growth habits, namely upright, semi-upright and spreading (Figure 2).

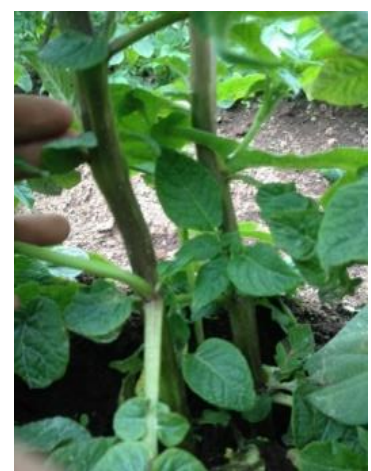

A

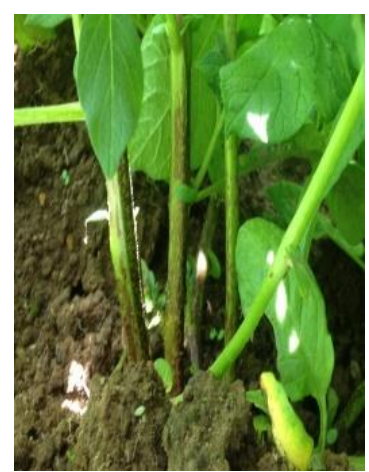

B

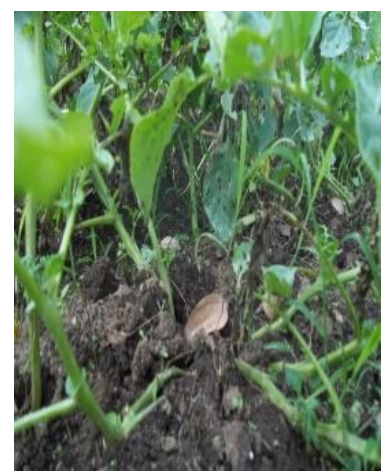

$\mathbf{C}$

Figure 2:-The pattern of the potato plant growth habit (A) vertical (upright) (B) rather upright (semi-upright), and (C) spread (spreading)

The Granola variety of potato found in various places has the habit of spreading as shown in Figure 3 (C). According to Rukmana [13], plant stems are rectangular or pentagon, depending on the variety. Plant stems are nodular, hollow, and not woody, but rather hard when massaged. The diameter of small stems with height can reach 50-120 cm, spreading. Reddish green or purplish-green stems

\section{Leaves (Folium)}

Granola varieties of potato leaf is a compound leaf (folium compasitum) which has an open leaf arrangement, arranged opposite each other, alternately pinnate and hairy leaf surfaces. While the leaves of potato variety Granola in vitro only have a single leaf (Folium simplex) with the upper surface hairy leaves (Figure 3 ). 


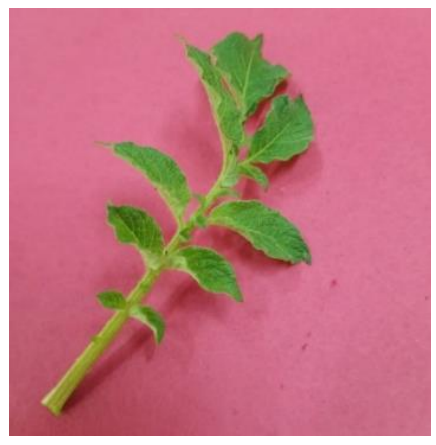

A

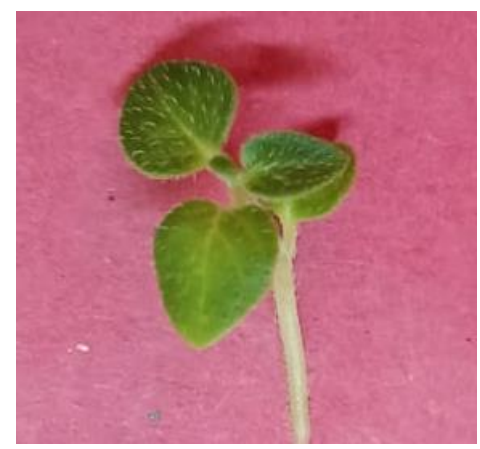

B

Figure 3:-Leaves compound (A) in -vivo and leaves tungal (B) in - vitro

Leaf is an organ whose growth is limited and generally symmetrical dorsiventral. Leaf flattening is related to its function in photosynthesis, because with the shape of the leaf, the area of leaf exposed to sunlight can be wider. The leaves are covered by both surfaces each by a layer of the epidermis. The outer surface of the epidermis is often coated with thick or thin cuticles. Stomata are on both sides. Mesophyll tissue does not experience differentiation into palisade tissue and spongy tissue, but consists of parenchymal cells with chloroplasts and intercellular space between them [10].

\section{Root (radix) -}

The root is part of the axis of the plant growing in the soil below the root surface first seed plants grown from root tip meristem apex in the embryo within the seed that germinated. In gymnosperms and dicots, the roots grow and grow to the primary roots with smaller branches.

Potatoes generally have a taproot and fiber roots system. Taproot can penetrate the soil to a depth of $45 \mathrm{~cm}$, while the roots of fibers generally grow spread (spread) to the side and penetrate the shallow soil. Whitish-colored plant roots very small and delicate. Among these roots there will be changes in form and function into tubers (stolons) which will then become potato tubers [14].

Propagation of potatoes with tissue culture (in vitro) on Murashige and Skoog media [15] requires auxin zpt to stimulate lateral root formation by activating perisicle cells to divide and develop and then give rise to roots. Auxin greatly influences the initiation of cell division, cell elongation, and promotes the formation of adventitious roots [16] Therefore the roots formed in in vitro potato plants are rooted in fibers which have many adventitious roots.

Observation of potato roots in vivo on Granola potato varieties has different root morphology with potatoes in vitro (Figure 4.). In in vivo potatoes the roots are tapered (radix primaria) and in vitro potatoes have fibrous roots (radix adventicia)

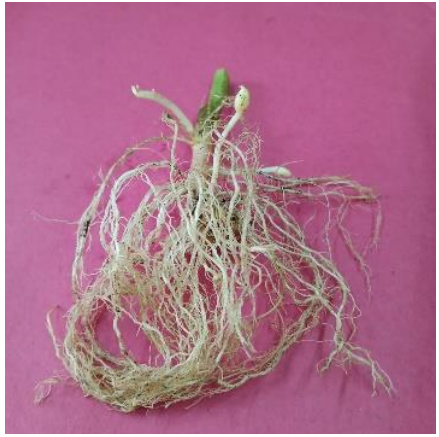

A

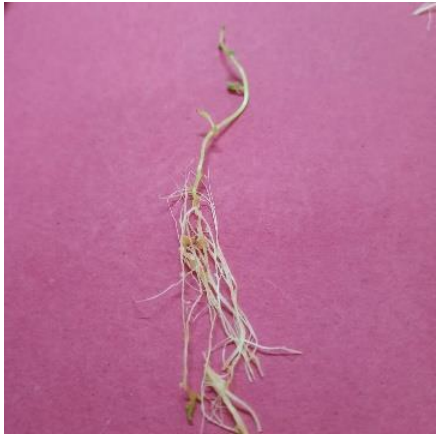

$\mathrm{B}$

Bulbs -

Figure 4:-The roots of potato (A) In - vivo (B) In - vitro

Bulbs are formed of side branches among the roots. The process of tuber formation is characterized by stopping the elongated growth of the stolon followed by enlargement so that the stolon swells. Tubers function to store food ingredients such as carbohydrates, proteins, fats, vitamins, minerals, and water [17] Potatoes themselves are tubers 
that are formed from stems called tuber caulogenum. Sunarjono [18] added that potatoes are a type of tubers which has scaly buds that can become new plants. The shape of the potato tuber varieties of Granola in vivo and in vitro are oval in shape with the smoothness of the skin being medium yellow potatoes, shallow bulb eyes and fleshy light yellow (Figure 5).

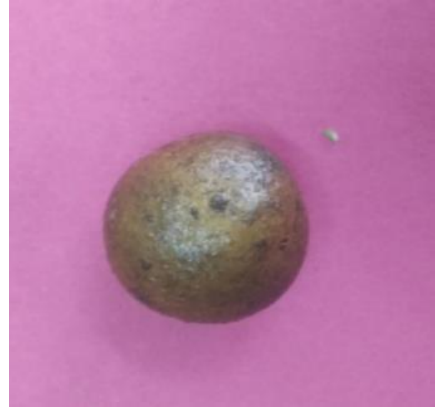

A

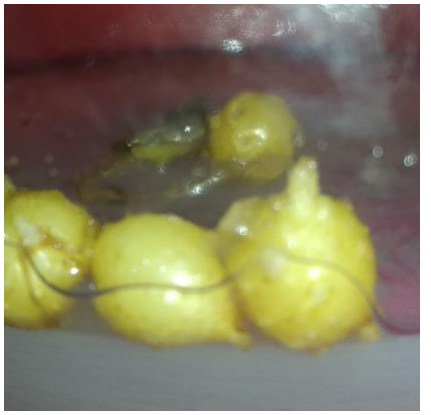

B

\section{Potato tubers -}

Figure 5:-(A) in -vivo and (B) in - vitro

The skin surface is getting old potato tubers stored consumption showed a shrinkage in line with the magnitude of shrinkage diameter._The change in the surface of the consumption potato tuber skin is also caused by the activity of respiration in harvested products such as on the potato tuber [19].

\section{Characterization Anatomy -}

The anatomical characteristics of plants that can be observed include the cell structure and the constituent tissue of the plant. Anatomical structure that can be used as a reference in the characterization of plants. According Handayani and Evita [20] in young dicotyledonous stems there are three regions namely the epidermis, cortex and stele. The epidermis is composed of a single layer of cells and an outer portion of the stem. The area next to the epidermis is the cortex, and on the inside of the cortex is limited by perisikel. The cortex is divided into two areas: the area kolenkim and parenchymal area. Kolenkim position below the epidermis and parenchyma on the inside kolenkim. Stele consists of perisikel, vascular bundle and pith. Vascular bundle in whorls. Each beam consists of xylem, cambium and phloem. The vascular bundles are spread, including the pith so there is no clear boundary between the cortex and the pith. Anatomy of in vitro potato stems is shown in Figure 6.

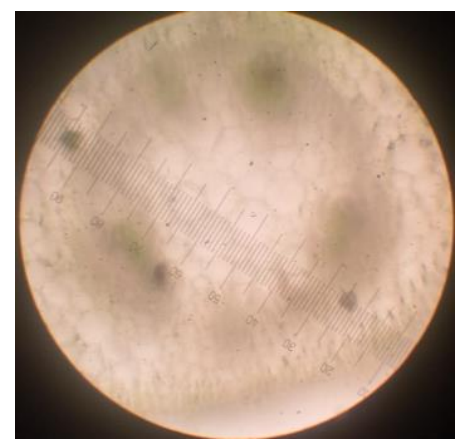

Figure 6:-Anatomy of in vitro potato stems at a magnification of $40 \times 10$

The roots are formed from three type of tissue including, dermal tissue, parenchymal tissue, and the vascular tissue. he cortex is composed of layers of the epidermis and parenchyma. Epidermis layer is the outer portion of the root. At the bottom of the epidermis there is a network of sclerenkim, cortical parenchyma tissue that has a lot of space between cells. Between the cortex and the vascular tissue there is a layer of cells that has a dense structure similar to the epidermis, which is called the endodermis. Vascular tissue consists of alternating xylem and phloem bundles arranged in a circle. On the outside of the cylindrical vessel is a layer of cells called perisicles [20]. 


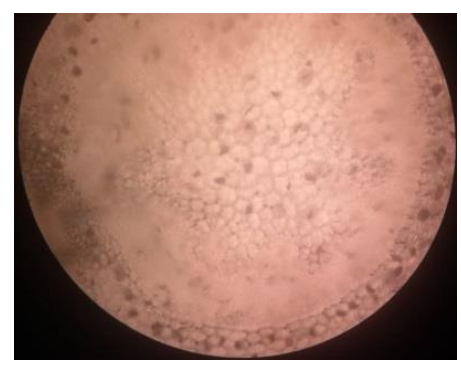

Figure 7:-The anatomy of potato roots in vivo

\section{Stomata-}

Stomata are gaps in the epidermis that are bounded by two special epidermal cells, namely guard cells. Cells that surround the stomata can be shaped the same or different from other epidermal cells. Different cells that form the cell is called a subsidiary cell. Subsidiary cells play a role in osmotic changes that cause cell movement closing the set width of the gap [21]. Subsidiary cells morphologically distinct from other epidermal cells, which consists of two or more subsidiary cells that surround the guard cell, which is related function [22]

The anatomical structure observed in this study was the stomata found on the underside of the leaves and the upper surface of the potato leaves of Granola varieties in vivo and in vitro. According to Fahn [6] potatoes are anisocytic stomata because they belong to the Solanaceae family. However, there are differences in stomata density between the leaves of the Granola variety in vivo and in vitro as shown in Figure 8.

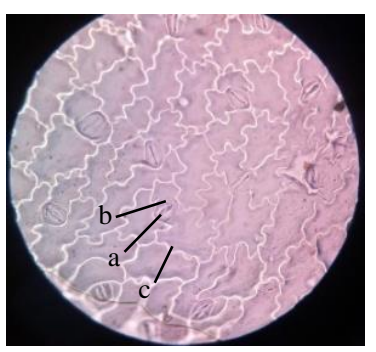

A

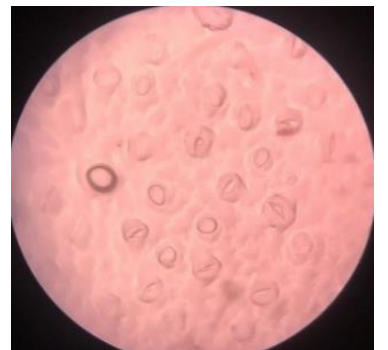

B

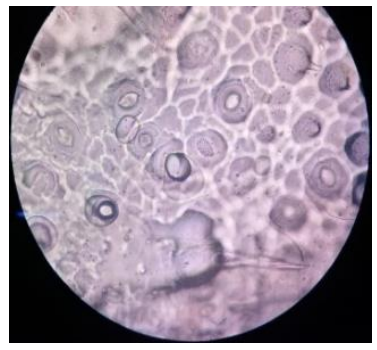

$\mathrm{C}$

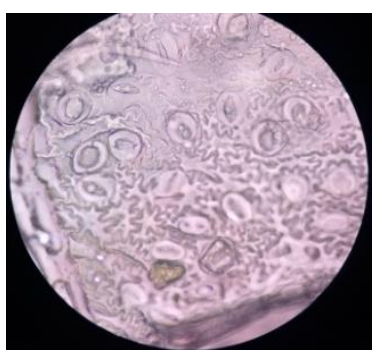

$\mathrm{D}$

Figure 8:-Comparison of stomata in the upper and lower leaves of potato in vivo and in vitro (A) the upper leaves of potato in vivo (B) the lower of leaves in vivo (C) the upper leaves in vitro and (D) the lower of leaves in vitro

Description: $\mathrm{a}=$ pore stomata

$\mathrm{b}=$ guard cells

$\mathrm{c}=$ subsidiary cell

Stomata is a modification of specialized epidermal tissue into an organ that acts as the entry and exit of air and water in the leaves [7]. Rompas [8] states that the stomata are generally found on the undersides of leaves, but there are some species of plant stomata on the upper and lower surfaces of the leaves. Location of stomata on the leaves of dicotyledonous generally spread on epidermisnya eg on potato. This is presumably related to genetic and morphological properties in dicotyledonous plants and monocots [23].

Type of stomata in dicotyledonous based on the composition of epidermal cells adjacent to the existing neighboring cells 5 are anomocytic, anisocytic, parasitic, diacitic and actinositic. Stomata of potato including anisositik that ach guard cell is surrounded by 3 neighboring cells that are not the same size [6]. It can be seen the comparison of the density and stomata index of upper and lower in vivo and in vitro potato plants in Table 2.

Table 2 shows the average density of stomata on potato in vivo at the top of the leaf (epistomatik) is greater, namely 0,035 compared with the upper leaf stomatal density (epistomatik) plants in vitro is 0.031 . In contrast to the underside of leaves (hipostomatik) stomatal density of potato plants in vitro is larger, ie 0.066 compared to the density of stomata of the underside of leaves (hipostomatik) potato plants in vivo $0.055 \mathrm{um}$ 
Table 2:-Comparison of density and stomatal index above and below the potato plant stomata in vivo and in vitro

\begin{tabular}{|l|c|c|c|c|c|}
\hline \multirow{2}{*}{ potato leaf } & \multirow{2}{*}{ repeat } & \multicolumn{2}{c|}{ Stomata density (um) } & \multicolumn{2}{c|}{ Stomata index (\%) } \\
\cline { 3 - 6 } & & In - vivo & In - vitro & In - vivo & In - vitro \\
\hline \multirow{2}{*}{$\begin{array}{l}\text { The top of the leaf } \\
\text { (epistomatik) }\end{array}$} & 1 & 0.048 & 0.031 & 13.86 & $19: 17$ \\
\cline { 2 - 6 } & 2 & 0.035 & 0.042 & $08: 04$ & - \\
\cline { 2 - 6 } & 3 & 0.022 & 0.022 & $05: 49$ & - \\
\hline Average & 1 & 0.035 & 0.031 & $09: 13$ & $19: 17$ \\
\hline \multirow{2}{*}{$\begin{array}{l}\text { The underside of the } \\
\text { leaves (hipostomatik) }\end{array}$} & 2 & 0.066 & 0.088 & 21.97 & 34.37 \\
\cline { 2 - 6 } & 3 & 0.057 & 0.048 & - & - \\
\hline Average & & 0.044 & 0.064 & - & - \\
\hline
\end{tabular}

Description: (-) cells epidermisnya not clear that it can not be calculated

The average index of stomata in Table 2 shows the stomata index (\%) at the upper of the potato leaf (epistomatik) and lower sections thereof (hipostomatik) potato plants in vitro is greater than the leaves of potato plants in vivo. Nurhidayah et al. [24] reported a potato leaf stomata influenced by the environment.

Different types of stomata can occur in the same family or can also occur in the organ and the same species [25] According Djumali and Mulyaningsih [26], the process of opening and closing of stomata affect the availability of $\mathrm{CO}_{2}$ in the leaves, while the thickening process leaves affects the amount of light-harvesting apparatus in the leaves. The greater the higher the intensity of light up to a certain level will be followed by greater stomatal opening and the greater the rate of transpiration and the results of this study found that the old leaf stomata chlorophyll content average is higher than the chlorophyll content of young leaves [27].

\section{The starch content -}

Starch is a carbohydrate which is a polysaccharide resulting from the synthesis of green plants through the process of photosynthesis and consists of amylose and amylopectin. Starch has a granular crystalline form that is insoluble in water at room temperature which has the size and shape depending on the type of plant. The process of isolating amylose and amylopectin from potato starch resulted in a significant amylose and amylopectin\% $97.98 \%$ amylose from amylose-rich starch A and 98.96\% amylopectin from starch B-rich amylopectin. [28]. According to Sjamisiah et al., [29] starch levels found in potatoes are around $22 \%-28 \%$.

In its original form naturally starch are small granules are often called granules. The modified starch is starch treated with the aim to produce better properties to improve the properties before [30]. In Figure 8 we can see the difference in starch formed in potato plants in vivo more than in vitro potato plants shown by granules or small granules seen in Figures 8 A and 8 B. Maulida [31] adds the height of potato plants Medians affect starch levels and amylopectin levels.

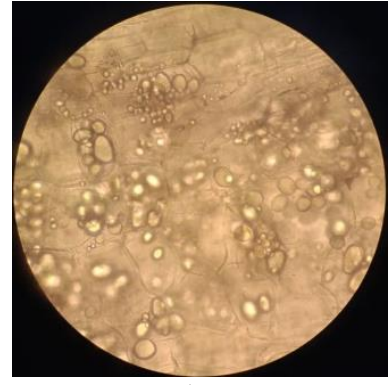

A

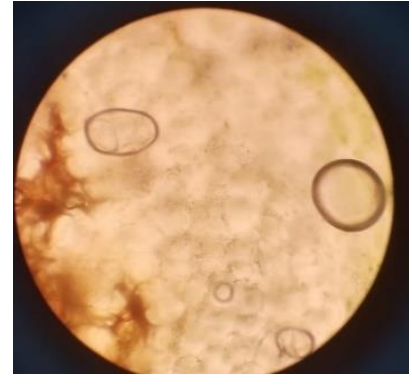

B

Figure 8:-Potato Starch (A) in -vivo and (B) in - vitro

High temperatures reduce the translocation of photosynthesis to sweet potatoes and increase their translocation into leaves and stems, so that the starch content in sweet potatoes is small, but there is more sugar in the upper plants. $72 \%$ decrease in sucrose synthase enzyme activity occurs in potatoes which are sensitive to high temperatures, while 
in tolerant potatoes it is only reduced by $59 \%$, besides that the enzyme activity that plays a role in starch metabolism will be suppressed at $30{ }^{\circ} \mathrm{C}$ soil temperature conditions, resulting in inhibition the conversion of sugar into [32].

Starch in leaves and stored in the chloroplasts, the storage organs, carbohydrates stored in amiloplas formed as the result of translocation of sucrose or other carbohydrates from leaves. Starch is always in one item or several items in the plastid [33].

\section{Content of Chlorophyll}

Chlorophyll is a major component in the process of photosynthesis. The higher chlorophyll content is associated with an increase in photosynthesis and an increase in photosynthates and their utilization for plant growth processes [35]. In higher plants there are 2 kinds of chlorophyll, namely; chlorophyll a (C55H72O5N4Mg) dark green and chlorophyll $\mathrm{b}\left(\mathrm{C}_{55} \mathrm{H}_{70} \mathrm{O}_{6} \mathrm{~N}_{4} \mathrm{Mg}\right)$. Its light green. Chlorophyll-a and $\mathrm{b}$ are most strongly absorbing light in the red $(600-700 \mathrm{~nm})$ while the least green light $(500-600 \mathrm{~nm})$. While the blue light of the spectrum is absorbed by carotenoids. Carotenoids play a role to help absorb the light so that the solar spectrum can be put to better use. Carotenoids absorbed energy is passed on to the chlorophyll-a to be absorbed is used in the process of photosynthesis, as well as chlorophyll-b. The energy absorbed by chlorophyll $b$ and carotenoids forwarded to chlorophyll for use in photosynthesis process of phase I (light reaction) consisting of photosystem I and II, as well as chlorophyll b.

Table 3:-Chlorophyll content of potato leaves of Granola varieties in vivo and in vitro

\begin{tabular}{|l|c|c|c|c|}
\hline \multirow{3}{*}{ Treatment } & \multirow{2}{*}{ repeat } & \multicolumn{3}{|c|}{ Chlorophyll $(\boldsymbol{\mu g} / \mathbf{~ m l})$} \\
\cline { 3 - 5 } & & $\mathbf{a}$ & $\mathbf{B}$ & Total \\
\hline \multirow{3}{*}{ In - vivo } & 1 & 1.52 & 0.74 & 2.26 \\
\cline { 2 - 5 } & 2 & 1.53 & 0.75 & 2.29 \\
\cline { 2 - 5 } & 3 & 1.61 & 0.81 & 2.41 \\
\hline Average & & 1.55 & 0.77 & 2,32 \\
\hline \multirow{3}{*}{ nn - vitro } & 1 & 1.12 & 0.67 & 1.80 \\
\cline { 2 - 5 } & 2 & 1.22 & 0.63 & 1.85 \\
\cline { 2 - 5 } & 3 & 1.03 & 0.53 & 1.56 \\
\hline Average & 1.12 & 0.61 & \\
\hline \multicolumn{2}{|l|}{} & & & 1.74 \\
\hline
\end{tabular}

In Table 3 the analysis of chlorophyll a, b and total shows that the in vivo variety of Granola potatoes is higher than that of in vitro Granola potatoes, which is $2.32 \mu \mathrm{g} / \mathrm{ml}$ in total chlorophyll, $1.55 \mu \mathrm{g} / \mathrm{ml}$ and $0.77 \mu \mathrm{g} / \mathrm{ml}$ in chlorophyll a and b. Ai and Banyo [35] state that chlorophyll is the main factor affecting photosynthesis. Photosynthesis is the process of change of inorganic compounds $\left(\mathrm{CO}_{2}\right.$ and $\left.\mathrm{H}_{2} \mathrm{O}\right)$ into organic compounds (carbohydrates) and $\mathrm{O}_{2}$ with the aid of sunlight. Chlorophyll is the main pigment found in chloroplasts. Chlorophyll causes the light turns into electromagnetic radiation in the visible spectrum (visible).Differences in chlorophyll a and $\mathrm{b}$ are the $\mathrm{C} 3$ atom contained methyl group to chlorophyll a to chlorophyll $\mathrm{b}$ aldehydes. Therefore both have different absorption of light waves. The role of the pigment chlorophyll is in the photosystem reaction.

According to Salisbury and Ross [11] Chlorophyll a plays a direct role in light reactions, converting solar energy into chemical energy, but other pigments in thylakoid membranes can absorb light and transfer energy to chlorophyll $\mathrm{a}$ in light reactions. One of these accessories pigments is another form of chlorophyll, namely chlorophyll b. chlorophyll $\mathrm{a}$ is blue-green while chlorophyll $\mathrm{b}$ is yellow-green. When photons of sunlight are absorbed by chlorophyll b, energy is channeled into chlorophyll a so that it is as if chlorophyll has absorbed the photon. The formation of chlorophyll $\mathrm{b}$ requires $\mathrm{O} 2$ and NADPH2 with the help of the enzyme chlorophyll a oxygenasie (CAO).

\section{Conclusion:-}

Based on research that has been done can be concluded that:

1. There are differences in morphology between potato plants in vitro and in vivo

2. There are anatomical differences between the anatomy of the leaves and stems of potato plants in vitro and in vivo

3. The results showed a stomata on both upper and lower leaf surfaces

4. Under stomata stomata are more numerous than the top. 
5. The content of chlorophyll $\mathrm{a}, \mathrm{b}$ and total potato crop in vitro less tight in vivo

\section{Acknowledgements:-}

Thanks to Mr. Dean of the Faculty of Agriculture, University of Andalas, which has funded research through correspond BOPTN Fund agreement No. 01 / PL / SPK / PNP / Faperta-Unand / 2019, Head of UPPM Faculty of Agriculture, and all those who have helped for the implementation of this study.

\section{Reference:-}

1. Hawkes, J. G. 1990. The Potato, Evolusion, Biodiversity, and Genetic resources. Balhaven Press. London

2. Sugiharyanto. 2008. Prospek Pengembangan Budidaya Tanaman Kentang di Indonesia. Geomedia 6(2):43-53

3. Suwinda R. 2016. Penampilan Morfologi Kentang (Soloanum tuberosum L.) di Sumatera Barat. [Sripsi]. Fakultas Pertanian Universitas Andalas

4. Sari D C. 2013. Induksi Umbi Mikro Kentang (Solanum tuberosum L.) Secara In Vitro pada Suhu Medium dengan Beberapa Konsentrasi Gula [Skripsi]. Institut Pertanian Bogor.

5. Pandey, B.P. 1982. Palnt Anatomy. S Chand and Company. New Delhi

6. Fahn, A . 1992. Anatomi Tumbuhan. Yogyakarta : Gadjah Mada Press

7. Retno,R.S. 2015. Identifikasi Tipe Stomata Pada Daun Tumbuhan Xerofit (Euphorbia splendess), Hidrofit (Ipomea aquatic), dan Mesofit (Hibiscus rosa-sinensis). Florea 2(2):(28-32).

8. Rompas Y. 2011. Struktur Sel Epidermis dan Stomata Daun Beberapa Tumbuhan Suku Orchidaceae. Jurnal Bioslogos 1(1): 1-7.

9. UPOV. 2004. Guidelines for The Conduct of Test for Distincness, Homogenity and Stability of Potato. International Union for The Protection of New Varieties of Plants.

10. Tjitrosoepomo, G., 2004. Morfologi Tumbuhan. Gadjah Mada Universiy Press. Yogyakarta, 256p

11. Salisbury F. B., and C. W. Ross. 1995. Fisiologi Tumbuhan Jilid 3. Translator: ITB Bandung. Terjemahan dari : Plant Physiology.

12. Handayani T., P. Basunanda, R.H. Murti and E. Sofiari. 2013. Morphological Changes and Tolerance of Potato Plants To Heat Stress.J. Hort. 23(4):318-328

13. Rukmana R. 2002. Usaha Tani Kentang Sistem Mulsa Plastik. Kanisius. Yogyakarta.

14. Pitojo S. 2004. Benih Kentang. Kanisius. Yogyakarta. 133p

15. Warnita. 2008. Modifikasi Media Pengumbian Kentang dengan Beberapa Zat Penghambat Tumbuh. Jerami Jurnal Agronomi Indonesia. 1(1) : $50-53$.

16. Lestari F.W., E. Suminar and S. Mubarok. Pengujian Berbagai Eksplan Kentang (Solanum tuberosum L.) dengan Penggunaan Konsentrasi BAP dan NAA yang berbeda. Jurnal Agro 5(1):66-75

17. Samadi. 2007. Kentang dan Analisis Usaha Tani. Kanisius. Yogyakarta. 117p

18. Sunarjono, H. 2007. Petunjuk Praktis Budidaya Kentang. Agromedia. Jakarta. 110 hal.

19. Purnomo E., S. W. A. Suedy and S. Haryanti. 2014. Perubahan Morfologi Umbi Kentang Konsumsi (Solanum tuberosum L.) Setelah Perlakuan Cara dan Waktu Penyipanan yang Berbeda. Jurnal Biologi 3(1):40-48.

20. Handayani H.N. and Evita. 2018. Modol Pengembangan Keprofesian Berkelanjutan: Profesional Sel, Jaringan, Organ. Kementrian Pendidikan dan Kebudiyaan Direktorat Jendral dan Tenaga Kependidikan.

21. Hidayat E.B. 1995. Anatomi Tumbuhan. Penerbit IPB: Bandung.

22. Mulyani S. 2006. Anatomi Tumbuhan. Penerbit kasinus: Yogyakarta

23. Loveless. A.R. 1987. Prinsip-prinsip Biologi Tumbuhan untuk daerah Tropik. Jakarta : PT Gramedia

24. Nurhidayah, E. Anggarwulan and Solichatun. Kandungan Klorofil pada Daun Tanaman Kentang (Solanum tuberosum L.) di Sekitar Kawah Sikidang Dataran Tinggi Dieng. Biosmart. 3(1):35-39.

25. Sarjani, T. M., Mawardi, E. S. Pandia, and D. Wulandari. 2017. Identifikasi morfologi dan anatomi tipe stomata famili piperaceae di Kota Langsa. Jurnal IPA dan Pembelajaran IPA (JIPI), 1(2): 182-191.

26. Djumali and S. Mulyaningsih. 2013. Pengaruh Cekaman Air Terhadap Karakter Fisiologis Tembakau Temanggung dan Kaitannya dengan Hasil dan Kadar Nikotin Rajangan Kering. Buletin Tanaman Tembakau, Serat \& Minyak Industri 5(2):78-90.

27. Hidayati N., M. Mansur, and T. Juhaeti. 2013. Variasi Serapan Karbondioksida $\left(\mathrm{CO}_{2}\right)$ Jenis-jenis Pohon di "Ecopark", Cibodong dan Kaitannya dengan Potensi Mitigasi Gas Rumah Kaca. Bulutin Kebun Raya 16(1):3850.

28. Niken A.H and A.Y. Dicky. 2013. Isolasi Amilosa dan Amilopektin dari Pati Kentang. J. Teknologi Kimia dan Industri 2(3):57-62 
29. Sjamsiah, J. Saokani and Lismawati. 2017. Karakteristik Edible film dari Pati Kentang (Solanum tuberosum L.) dengan Penambahan Gliserol. J. Al-kimia 5(2):181-192

30. Koswara, S. 2009. Teknologi Modifikasi Pati. Ebook Pangan. [Online] http://tekpan.unimus.ac.id/wp content/uploads/2013/07/Tekn ologi-Pengolahan-Beras-Teori-dan-Praktek.pdf. Access 22 November 2019 07:51 AM.

31. Maulida K. E. 2018. Sifat Fisikomia Pati Kentang (Solanum tuberosum L.) Varietas Medians Termodifikasi Cross-linking yang Pengaruhi Variasi Konsentrasi Monosodium Phosphate 9 MSP) dan Ketinggian Penanaman yang Berbeda. [Skripsi]. Program Studi Teknologi Pangan Fakultas Teknik: Universitas Pasundan : Bandung

32. Prabaningrum, L. 2014. Teknologi Budidaya Kentang di Dataran Medium. Balai Penelitian Tanaman Sayuran.

33. Sari A.K., S. Indriani, G. Ekowati and J. Batoro. 2017. Keragaman Struktur Butir Amilum, Kadar Tepung, dan Clustering Delapan Taksa Tanaman Berumbi di Desa Simo Kecamatan Kendal Kabupaten Ngawi. J. Biotropika 5(1):14-21

34. Raka I.G.N., K. Khalimi, I.D.N. Nyana and I.K. Siadi. 2012. Aplikasi Rhizobakteri Pantea agglomerans untuk Meningkatkan Pertumbuhan dan Hasil Tanaman Jagung (Zea mays) Varietas Hibrida BISI-2. Agrotrop 2(1):1-9

35. Ai, N.S. and Y. Banyo. 2011. Konsentrasi Klorofil Daun Sebagai Indikator Kekurangan Air Pada Tanaman. J. Ilmiah Sains 11: $166-171$. 